\title{
COLONISATION OF RENOVATED PASTURES IN WAIKATO BY FOUR COLEOPTERAN SPECIES
}

\author{
S. HARDWICK \\ AgResearch, Ruakura Research Centre, Private Bag 3123, Hamilton \\ Corresponding author: scott.hardwick@agresearch.co.nz
}

\begin{abstract}
In autumn 1998 a farm scale replicated field trial was established in Waikato, New Zealand, to measure the productivity of combinations of old and new ryegrass and white clover cultivars. Colonisation in the first two years of the trial by Costelytra zealandica, Heteronychus arator, Naupactus leucoloma and Sitona lepidus was monitored. By the end of winter 2000, no difference in densities of any of the pest species monitored could be attributed to cultivar treatments. However, dispersal behaviour and soil type did have a significant effect on pest densities. Naupactus leucoloma, which disperses by walking, was found in greatest densities on the edges of the trial. Costelytra zealandica, which disperses by flying, was initially aggregated in paddocks with shelterbelts. Heavy infestations of $H$. arator, which also disperses by flying, were associated with good soil drainage. Sitona lepidus, which disperses by flying, was evenly distributed across the trial.
\end{abstract}

Keywords: Pasture renovation, scarabaeidae, curculionidae, colonisation.

\section{INTRODUCTION}

Pastoral agriculture in New Zealand is largely based on the use of perennial ryegrass (Lolium perenne L.) and white clover (Trifolium repens L.). Grass grub (Costelytra zealandica (White)), black beetle (Heteronychus arator (Fabricius)) (Coleoptera: Scarabaeidae), whitefringed weevil (Naupactus leucoloma Boheman) and clover root weevil (Sitona lepidus Gyllenhal) (Coleoptera: Curculionidae) are four coleopteran pest species that inhabit improved pastures in New Zealand. In the northern half of the North Island these four pest species are often sympatric. Costelytra zealandica and H. arator are univoltine species (Henzell et al. 1980; King et al. 1981), S. lepidus is bivoltine (Gerard et al. 1999) while $N$. lecoloma takes 8-24 months to complete a generation (Hardwick 1999). Heteronychus arator, C. zealandica and S. lepidus disperse away from previously occupied areas by flights occurring in autumn, spring and summer respectively (Henzell et al. 1980; Watson 1980; Addison \& Hardwick, unpubl. data). Dispersal by adult $N$. leucoloma, which is flightless, is undertaken by walking (Steven 1980).

Root herbivoury by the larvae of these coleopteran species can influence the productivity of pasture systems by causing reductions in overall plant dry matter production, significant changes in pasture composition and decreases in the nutritional value of pasture (e.g. Kain et al. 1979; King et al. 1982; Gerard 2002). With the exception of $H$. arator, adults are not considered to be economically damaging in established pasture. However, feeding by adult $S$. lepidus can cause significant mortality to white clover seedlings (P.J. Addison, pers. comm.). In pasture both the adults and larvae of $H$. arator feed on graminaceous species (King et al. 1982) while S. lepidus feeding is confined to plants in the genus Trifolium with a strong preference shown for white clover (Clements \& Murray 1991). Feeding by $C$. zealandica occurs on both grasses and clovers with a preference for the latter being exhibited (Kain et al. 1979). Naupactus leucoloma larvae feed on a range of plant species. However, in pasture evidence suggests that there is a strong preference shown for broadleaf plant species such as white clover (e.g. King et al. 1982; Hardwick 1999). 
In 1998 a farm scale trial to investigate production from dairy cows grazing different combinations of ryegrass and white clover cultivars was established (Eerens et al. 2001). The trial design presented an opportunity to monitor patterns of colonisation by pest species in a number of treatments over a relatively large area. This study outlines the results of monitoring $C$. zealandica, $H$. arator, $N$. leucoloma and $S$. lepidus populations on the trial in the two years following pasture establishment.

\section{Trial design and pasture establishment}

\section{MATERIALS AND METHODS}

A detailed description of the trial is outlined in Eerens et al. (2001). The trial covered 48 ha on Dexcel's Scott Farm on the outskirts of Hamilton. Four pasture treatments consisting of perennial ryegrass and white clover cultivar combinations were used in the trial (Table 1). These were mixes of representative perennial ryegrasses available in the 1980s (80R) or late 1990s (98R), and clovers available in the 1960s (60C) or late 1990s (98C). To ensure that treatments reflected the standard dairy pastures all perennial ryegrass cultivars used were infected with wild type endophyte (Neotyphodium lolii Latch Christensen \& Samuels: Bacon Glen \& Hanlin). Treatment paddocks were 1 ha in size, permanently split into two 0.5 ha paddocks, using a randomised block design so that treatments were balanced across the range of soils occurring at the site. These included Te Rapa humic and peaty silt loam variants, Te Kowhai silt loam and Matangi silt loam. Disjunct shelterbelts of barberry (Berberis glaucocarpa) (ca 2-3 m in height), black wattle (Racosperma mearnsii) (ca 2-5 m), poplar (Populus sp.) (ca 15-25 m), alder (Alnus sp.) (ca 15-25 m), oak (Quercus sp.) (ca 10-20 m) and pine (Pinus radiata) (ca 5-25 m) grown alone or as mixed plantings were present in and around the trial area. Each treatment was replicated three times giving 12 farmlets each of 4 ha (Eerens et al. 2001).

Existing pasture at the trial site was sprayed out with glyphosate at the manufacturer's recommended rate, cultivated and fallowed over the summer of 1998 (Eerens et al. 2001). Seed mixtures were sown during April 1998 at a bare seed rate of $18 \mathrm{~kg} / \mathrm{hat}$ total ryegrass and $3 \mathrm{~kg} /$ ha total white clover. To minimise the effect of invertebrate feeding on white clover establishment, seed was Superstrike ${ }^{\mathrm{TM}}$ and imidacloprid (Gaucho ${ }^{\mathrm{TM}}$ ) treated in accordance with manufacturer's recommendations (Eerens et al. 2001).

TABLE 1: Perennial ryegrass and white clover cultivars used and endophyte (N. lolii) infection (\%) in ryegrass for the four cultivar treatments (adapted from Eerens et al. 2001).

\begin{tabular}{lccc}
\hline Treatment & Perennial ryegrass cultivars & $\begin{array}{c}\text { Endophyte } \\
\text { infection }\end{array}$ & Clover cultivars \\
\hline 80R60C & Ellett, Nui, Yatsyn & $69 \%$ & Huia, Pitau \\
98R60C & Aries HD, Bronsyn, Samson & $92 \%$ & Huia, Pitau \\
80R98C & Ellett, Nui, Yatsyn & $69 \%$ & Challenge, Sustain \\
98R98C & Aries HD, Bronsyn, Samson & $92 \%$ & Challenge, Sustain \\
\hline
\end{tabular}

\section{Invertebrate Monitoring}

Sampling was undertaken to estimate the density of soil and surface dwelling invertebrates in each paddock in the first week of October (spring), January (summer) April (autumn) and June (winter) of each year during October 1998-June 2000. Soil dwelling life stages were sampled by taking 10 randomly located soil cores $(100 \mathrm{~mm}$ diameter) to a depth of $200 \mathrm{~mm}$. Cores were then placed into labelled plastic bags in lots of five and kept at $5^{\circ} \mathrm{C}$ until processed. A wet sieving extraction process similar to that outlined by Kain \& Atkinson (1976) was used, except that three stainless steel sieves with aperture sizes of 3.2, 1 and $0.4 \mathrm{~mm}$ were used. All invertebrates were removed from the sieves and preserved in $70 \%$ ethanol solution before being identified and counted. 
Sampling for surface dwelling invertebrates involved taking 10 randomly located samples each consisting of five subsamples $178 \mathrm{~mm}$ in diameter $\left(0.025 \mathrm{~m}^{2}\right)$ using a Vortis sampler (Burkard Manufacturing Co. Ltd, Rickmansworth, England). Invertebrates collected were extracted directly into vials containing $70 \%$ ethanol. Once in the laboratory the invertebrates were separated from any plant material, identified, counted and recorded. In both sampling regimes a $10 \mathrm{~m}$ buffer within plot boundaries was not sampled.

\section{Data analysis}

Soil coring and Vortis sampling data were combined to give an overall population density (numbers $/ \mathrm{m}^{2}$ ) estimate for C. zealandica, H. arator, N. leucoloma and S. lepidus at each sampling date and is presented in Table 2. Density data was then pooled to give a single mean for each coleopteran species for the 1998-99 and 1999-00 growing seasons. The influence of the cultivar treatments, soil drainage (good, average and poor), paddock position (boundary or internal) and presence or absence of shelterbelts on paddock boundaries on the density of $C$. zealandica, $H$. arator, $N$. leucoloma and S. lepidus in years 1 and 2 of the monitoring programme was analysed in GenStat (version 7) using a Generalised Linear Model analysis. A Poisson distribution that allowed for extra-Poisson variation to minimise the influence of invertebrate aggregation effects was used in the analysis. This data is presented in Tables 3 and 4 as mean numbers per sampling date.

\section{RESULTS AND DISCUSSION}

The density of C. zealandica, H. arator, N. leucoloma and S. lepidus in the trial area was negligible at the time of pasture establishment (Table 2). Colonisation of the newly established trial was rapid. Dispersal of adult $C$. zealandica into the trial area occurred in late spring-early summer 1998 and gave rise to a generation of larvae that completed their development over the 1998/99 growing season (Table 2). Oviposition by adults from the first generation resulted in significant populations of C. zealandica in 1999/ 2000. Significant flight activity by $H$. arator resulted in the colonisation of the trial site in autumn 1999 (Table 2). Adult $H$. arator fed through the winter and completed oviposition in spring 1999. Resultant larvae completed their development over spring and summer before pupating and emerging as adults in autumn 2000. Naupactus leucoloma adults dispersed into the trial during the summer of 1998/99 (Table 2). Oviposition by N. leucoloma during summer-autumn 1998/99 gave rise to larvae that were present from late summer 1999 onwards. A significant proportion of these larvae completed their development and emerged as adults in summer 1999/00. This resulted in further larval recruitment in the autumn 2000 (Table 2). Significant flight activity by S. lepidus occurred throughout the summer of 1998/99. Substantial S. lepidus larval populations were present across the trial area from autumn 1999 onwards. For all four coleopteran species the patterns of colonisation in the trial area are similar to those reported previously (e.g. King \& East 1980; King et al. 1982; Popay 1992; Hardwick \& Prestidge 1994; Hardwick 1999; Gerard et al. 1999).

TABLE 2: Mean numbers $/ \mathrm{m}^{2}( \pm \mathrm{SEM})$ of $C$. zealandica, $H$. arator, $N$. leucoloma and $S$. lepidus at each sampling date.

\begin{tabular}{lrrrrr}
\hline & C. zealandica & \multicolumn{1}{c}{ H. arator } & \multicolumn{1}{c}{ N. leucoloma } & \multicolumn{2}{c}{ S. lepidus } \\
\hline Spring 1998 & $9.2 \pm 2.9$ & $0.2 \pm 0.3$ & $2.4 \pm 1.6$ & $15.0 \pm$ & 5.6 \\
Summer 1998/99 & $41.7 \pm 6.6$ & $1.4 \pm 1.6$ & $4.7 \pm 2.1$ & $103.3 \pm$ & 9.6 \\
Autumn 1999 & $36.1 \pm 6.1$ & $11.6 \pm 6.8$ & $14.5 \pm 3.8$ & $541.2 \pm 23.5$ \\
Winter 1999 & $28.6 \pm 5.5$ & $7.3 \pm 4.4$ & $26.1 \pm 5.7$ & $623.1 \pm 25.2$ \\
Spring 1999 & $20.1 \pm 5.2$ & $21.7 \pm 10.8$ & $28.0 \pm 5.3$ & $418.5 \pm 21.4$ \\
Summer 1999/00 & $145.1 \pm 12.1$ & $9.6 \pm 5.4$ & $46.0 \pm 6.8$ & $653.1 \pm 25.9$ \\
Autumn 2000 & $124.5 \pm 11.6$ & $9.1 \pm 5.3$ & $148.5 \pm 12.5$ & $541.4 \pm 23.5$ \\
Winter 2000 & $113.2 \pm 11.0$ & $8.5 \pm 4.7$ & $202.6 \pm 14.6$ & $1369.1 \pm 37.6$ \\
\hline
\end{tabular}


Perennial ryegrass and white clover cultivar treatments had no significant $(\mathrm{P}>0.05)$ effect on the ability of the four species to colonise and occupy the trial area since densities of each species were similar across all treatments in all years of the trial. This observation is not unexpected as newly established ryegrass-white clover pasture that has a relatively low population of pest species present is likely to represent a relatively uniform and under utilised resource for the establishment of populations of $C$. zealandica, H. arator, $N$. leucoloma and S. lepidus. Previous studies have shown that in most situations it takes two or more years for populations of the four pest species to build up to levels that can affect the production and composition of pastures (e.g. East \& King 1979; King \& East 1980; King et al. 1982; Popay 1992). Traits such as increased persistence and vigour on which new cultivars are selected may influence the size of invertebrate populations supported by a plant before negative effects occur and the plant is at a competitive disadvantage. It may be possible that the effects of the cultivar treatments only become visible in years following the current study.

Drainage within a paddock (Table 3), presence of shelterbelts and paddock location (Table 4) all had significant effects on the density of one or more of the four coleopteran species. Soil drainage characteristics were the most important factor influencing colonisation of the trial area by the coleopteran species being monitored (Table 3 ). In the 1998/99 growing season no $H$. arator established in paddocks with poor drainage compared with populations of $149 / \mathrm{m}^{2}$ in those with good drainage (Table 3 ). This trend was similar in the 1999/00 season when $H$. arator densities in well drained paddocks were 40 times that of paddocks with poor drainage (Table 3). Costelytra zealandica densities followed a similar pattern but to a lesser extent. Paddocks with good drainage had 1.5 and 6.5 times more C. zealandica than paddocks with poor drainage in 1998/99 and 1999/2000 respectively (Table 3). Naupactus leucoloma densities were only weakly influenced by soil drainage (Table 3). Throughout the trial, soil drainage status had no significant effect on the density of S. lepidus (Table 3). Wet winter/spring periods and poor drainage have been reported to cause high mortality and subsequent population fluctuations in C. zealandica and H. arator (East et al. 1981). While not reported before, results from this study suggest that periods of ponding and soil saturation in paddocks with poor drainage resulted in reductions in the observed differences in density of N. leucoloma.

TABLE 3: Mean numbers $/ \mathrm{m}^{2}( \pm \mathrm{SEM})$ at each sampling date of $C$. zealandica, $H$. arator, $N$. leucoloma and $S$. lepidus for areas differing in soil drainage in the 1998/99 and 1999/00 growing seasons.

\begin{tabular}{lcccc}
\hline & C. zealandica & H. arator & N. leucoloma & S. lepidus \\
\hline 1998/99 & & & & \\
Poor & $8.0 \pm 2.2$ & $0.0 \pm 0.0$ & $2.3 \pm 1.1$ & $102 \pm 14$ \\
Average & $8.8 \pm 1.5$ & $3.5 \pm 1.0$ & $4.2 \pm 1.3$ & $107 \pm 5$ \\
Good & $12.1 \pm 2.7$ & $149.0 \pm 125.0$ & $4.9 \pm 1.8$ & $90 \pm 12$ \\
Significance & $\mathrm{P}<0.001$ & $\mathrm{P}<0.001$ & $\mathrm{P}<0.01$ & $\mathrm{~ns}$ \\
$1999 / 00$ & & & & \\
Poor & $11.3 \pm 3.8$ & $6.0 \pm 13.1$ & $20.5 \pm 6.8$ & $206 \pm 14$ \\
Average & $27.7 \pm 2.8$ & $10.2 \pm 4.4$ & $34.7 \pm 4.3$ & $213 \pm 5$ \\
Good & $74.1 \pm 14.0$ & $240.0 \pm 250.0$ & $42.7 \pm 10.8$ & $208 \pm 13$ \\
Significance & $\mathrm{P}<0.001$ & $\mathrm{P}<0.001$ & $\mathrm{~ns}$ & $\mathrm{~ns}$ \\
\hline
\end{tabular}

Presence of a shelterbelt in a paddock had the greatest influence on densities of C. zealandica. In 1998/99 the density of C. zealandica in paddocks containing a shelterbelt was $15.0 \pm 3.1 / \mathrm{m}^{2}$ compared to $5.4 \pm 1.0 / \mathrm{m}^{2}$ in paddocks with no shelterbelt $(\mathrm{P}<0.01)$. There was no significant difference $(\mathrm{P}>0.05)$ between the density of $C$. zealandica in paddocks with and without shelterbelts in 1999/2000. The aggregation of C. zealandica 
populations in paddocks with shelterbelts is the result of behaviour associated with adult flight activity. Female $C$. zealandica lay most of their eggs almost immediately after emergence from the soil. However, further eggs are laid after flights at dusk when adults seek suitable foliage on which to feed (Robertson et al. 1999). During these flights C. zealandica orient towards high points in the horizon between dark ground and sky at dusk, thus aggregating them around the tallest vegetation in the vicinity (Farrell \& Wightman 1972).

In the 1999/2000 growing season the C. zealandica density in internal paddocks was 1.5 times greater than that in paddocks located on the boundary of the trial (Table 4).

TABLE 4: Mean numbers $/ \mathrm{m}^{2}( \pm$ SEM) at each sampling date of $C$. zealandica, $H$. arator, N. leucoloma and S. lepidus for boundary and internal locations within paddocks in the 1998/99 and 1999/00 growing seasons.

\begin{tabular}{lcccc}
\hline & C. zealandica & H. arator & N. leucoloma & S. lepidus \\
\hline 1998/99 & & & & \\
Boundary & $8.8 \pm 0.9$ & $29.6 \pm 23.6$ & $5.7 \pm 1.2$ & $103 \pm 5$ \\
$\quad$ Internal & $10.3 \pm 2.1$ & $22.9 \pm 16.6$ & $0.9 \pm 0.6$ & $106 \pm 7$ \\
Significance & $\mathrm{ns}$ & $\mathrm{ns}$ & $\mathrm{P}<0.001$ & $\mathrm{~ns}$ \\
$1999 / 00$ & & & & \\
$\quad$ Boundary & $28.4 \pm 2.6$ & $42.2 \pm 37.8$ & $39.8 \pm 3.5$ & $214 \pm 4$ \\
Internal & $44.5 \pm 4.9$ & $59.9 \pm 50.3$ & $24.2 \pm 4.4$ & $206 \pm 7$ \\
Significance & $\mathrm{P}<0.05$ & $\mathrm{~ns}$ & $\mathrm{P}<0.01$ & $\mathrm{~ns}$ \\
\hline
\end{tabular}

Paddock location within the trial had the greatest effect on densities of $N$. leucoloma. In the 1998/99 growing season the density of $N$. leucoloma in paddocks on the boundary of the trial area was 5 times greater than that in internal paddocks (Table 4). The trend continued into the 1999/2000 growing season, with the density of $N$. leucoloma in boundary paddocks being 1.6 times that of those in internal paddocks (Table 4). As $N$. leucoloma adults are flightless their dispersal is largely undertaken by walking or hitchhiking on farm and contracting equipment. Adults have been estimated to travel $1-20 \mathrm{~m}$ a day and up to 400-1200 $\mathrm{m}$ in a lifetime, depending on the vegetation in their path (Young \& App 1939; Steven 1980). If suitable host pants such as white clover are present then the rate of $N$. leucoloma movement is reduced (Steven 1980). In the current study, white clover made up 10-40\% of the total dry matter when $N$. leucoloma adults were present (Eerens et al. 2001). Therefore while it is theoretically possible $N$. leucoloma could have moved across the trial during the summer1998/99-autumn 1999 period, it is unlikely as adults would have had a reduced rate of daily movement in response to white clover once they entered the trial area.

In conclusion, the establishment of the C. zealandica, H. arator, N. leucoloma and $S$. lepidus populations was not influenced by ryegrass/white clover cultivars but was influenced by the soil drainage characteristics, presence of shelterbelts and method of adult dispersal.

\section{ACKNOWLEDGEMENTS}

The author would like to thank Neil Cox for advice on the statistical analysis, Pip Gerard, Wade Tozar, Fiona Kettlewell and Paul Addison for providing technical assistance, Richard Watson and Derrick Wilson for comments on an early draft of the manuscript, and Dexcel for providing access to the trial site. This work was funded by New Zealand Foundation for Research, Science and Technology.

\section{REFERENCES}

Clements, R.O.; Murray, P.J. 1991: Incidence and severity of pest damage to white clover. Aspects Appl. Biol. 27: 369-371. 
East, R.; King, P.D. 1977: Effects of botanical composition of pastures on insect pest populations. N. Z. Entomol. 6: 273-278.

Eerens, J.P.J.; Crush, J.R.; Woodward, S.L.; MacDonald, K.A. Carter, W.A. 2001: Milksolids production from different combinations of perennial ryegrass and white clover cultivars: 1 Trial design and pasture performance. Proc. $63^{\text {rd }}$ N.Z. Grasslands Assoc.: 91-96.

East, R.; King, P.D.; Watson, R.N. 1981: Population studies of grass grub (Costelytra zealandica and black beetle (Heteronychus arator) (Coleoptera: Scarabaeidae). N.Z. J. Ecol. 4: 56-64.

Farrell, J.A.K.; Wightman, J.A. 1972: Observations on flight and feeding activity of adult Costelytra zealandica (White) (Col. Scarabaeidae) in Nelson Province. N.Z. J. Agric. Res. 15: 893-903.

Gerard, P.J. 2002: Nodule damage by clover root weevil larvae in white clover swards. N.Z. Plant Prot. 55: 246-254.

Gerard, P.J.; Addison, P.J.; Hardwick, S.; Willoughby, B.E. 1999: Establishment of the invader: Insights into the life history and biology of Sitona lepidus in the Waikato region of New Zealand. Proc. $7^{\text {th }}$ Australasian Conf. Grassland Invert. Ecol.: 3551 .

Hardwick, S. 1999: Phenology and damage potential of whitefringed weevil (Naupactus leucoloma Boheman) in the northern North Island of New Zealand. Ph.D. thesis, Lincoln University, New Zealand. 234 p.

Hardwick; S.; Prestidge, R.A. 1994: Phenology of whitefringed weevil in pasture in northern New Zealand. Proc. $47^{\text {th }}$ N.Z. Plant Prot. Conf.: 257-260.

Henzell, R.F.; Lauren, D.R.; Cox, N.R. 1980: Monitoring Costelytra zealandica flight with sex attractant traps (Coleoptera: Scarabaeidae). Proc. $2^{\text {nd }}$ Australasian Conf. Grassland Invert. Ecol.: 125-128.

Kain, W.M.; Atkinson, D.S. 1976: Population studies of Costelytra zealandica (White) II. A rapid mechanical extraction method suitable for intensive sampling of $C$. zealandica and other scarabaeids. N.Z. J. Expr. Agric. 3: 177-180.

Kain, W.M.; Slay, M.W.; Atkinson, D.S. 1979: Evaluation of grass grub-plant interactions of grasses sown with and without white clover in the central Hawke's Bay. Proc. $32^{\text {nd }}$ N.Z. Weed and Pest Con. Conf:: 86-91.

King, P.D.; East, R. 1980: Effects of pasture composition on the dynamics of Heteronychus arator and Graphognathus leucoloma populations. Proc. $2^{\text {nd }}$ Australasian Conf. Grassland Invert. Ecol:: 79-82.

King, P.D.; Mercer, C.F.; Meekings, J.S. 1981: Ecology of black beetle. Heteronychus arator (Coleoptera: Scarabaeidae)-population studies. N. Z. J. Agric. Res. 24: 8797.

King, P.D.; Meekings, J.S.; Mercer, C.F. 1982: Effects of whitefringed weevil (Graphognathus leucoloma) and black beetle (Heteronychus arator) populations on pasture species. N. Z. J. Agric. Res. 25: 405-414.

Popay, A.J. 1982: Population regulation of Costelytra zealandica by pathogens in the North Island of New Zealand. In Jackson, T.A.; Glare, T.R. ed. Use of pathogens in scarab pest management. Intercept, Andover. Pp. 141-151.

Roberson, L.; Willoughby, B.; Ward, A.; Allsopp, P. 1999: Comparative review of population dynamics of scarab pests. Proc. $7^{\text {th }}$ Australasian Conf. Grassland Invert. Ecol:: 10-20.

Steven, D. 1980: Dispersal of Graphognathus leucoloma (Coleoptera: Curculionidae). Proc. $2^{\text {nd }}$ Australasian Conf. Grassland Invert. Ecol.: 146-148.

Watson, R.N. 1980: Dispersal and distribution of Heteronychus arator in New Zealand (Coleoptera: Scarabaeidae). Proc. $2^{\text {nd }}$ Australasian Conf. Grassland Invert. Ecol.: 149-152.

Young , H.C.; App, B.A. 1939: Biology of the whitefringed beetle (Naupactus leucoloma). Misc. Pub. USDA Bureau of Entomology and Plant Quarantine. 24 p. 